\title{
Isolation, characterization and antibacterial activity of actinomycetes from soils of the Langun- Gobingob Cave Complex in Calbiga, Samar
}

Jeffrae Isaac Albert R. Damayo ${ }^{1}$ and Rolly G. Fuentes ${ }^{1 *}$

The discovery of rare Actinomycetes from unexplored areas has proven to be a promising source of new antimicrobials. The Langun-Gobingob cave complex in Calbiga, Samar, Philippines is the second largest cave complex in Asia, yet this is the first reported search for actinomycetes conducted in the area. The main objective of this study was to assess the antibacterial activities of culturable actinomycetes from soil samples from the Langun-Gobingob cave complex. Five actinomycete colonies were isolated in pure culture from soil samples using Starch-Casein Agar medium. The isolates were identified by their morphological characteristics and they were characterized by $16 \mathrm{~S}$ rRNA sequencing. The sequences were matched to sequences uploaded to the $\mathrm{NCBI}$ Basic Local Alignment Search Tool (BLAST). Four of the isolates belonged to the Genus Streptomyces and one belonged to the Genus Nocardia. The antibacterial potential of the isolates was tested against gram-positive and gram-negative test bacteria. One Streptomyces isolate exhibited antibacterial activity against the two gram-positive test bacteria. The limited cave area sampled in this study leaves the cave complex mostly unexplored in the search for antibacterial secondary metabolites.

Keywords: Actinomycetes, 16s rRNA, starch-casein agar, BLAST

'Division of Natural Sciences and Mathematics, University of the Philippines Visayas Tacloban College, Magsaysay Boulevard, Tacloban City 6500, Philippines

\footnotetext{
*Corresponding Author. Address: Division of Natural Sciences and Mathematics, University of the Philippines Visayas Tacloban College, Magsaysay Boulevard, Tacloban City 6500, Philippines; Email: rgfuentes@up.edu.ph
} 


\section{INTRODUCTION}

The development of drug-resistance among many pathogens renders the common antibiotics impotent (Ventola 2015). The misuse of antibiotics, mutagenesis of resistant genes, and the horizontal transfer of these genes between bacteria have contributed to the rise of these antibiotic-resistant pathogens (Holmes et al 2016). This has invoked a search for novel antibiotics by the scientific community. A great portion of known antibiotics are derived from a group of widely-distributed bacteria known as actinomycetes (Solanki et al 2008). The search for actinomycetes from unexplored sources increases the probability of isolating actinomycete species which have not been isolated before. Their presence in isolated environments such as caves has sparked the interest of scientists in the past few years because these have led to the discovery of new bioactive compounds (Niyomvong et al 2012, Rangseekaew and Pathom-Aree 2019). These places commonly have microclimates which harbor their own ecosystems and ecology (Freitas 2010) where the scarce resources induce microorganisms to produce bactericidal compounds to eliminate competition (Nakaew et al 2009). To date, there are 47 species in 30 genera of actinobacteria from caves which have been identified and reported to be potential sources of bioactive compounds (Rangseekaew and Pathom-Aree 2019). The Calbiga karst in Samar, Philippines is the largest karst area in the country and second largest in Asia, covering about 900 square kilometers (Restificar et al 2006). It has 12 cave systems, the largest is the Langun-Gobingob which is nearly $5 \mathrm{~km}$ long. The difficulty in accessing the cave, and its declaration as a protected area, makes it a potentially untapped source of new knowledge and undiscovered biologically significant organisms. This paper presents the molecular identification and preliminary antibacterial potential screening of actinomycetes isolated from soil samples from the Langun-Gobingob cave complex.

\section{EXPERIMENTALSECTION}

\section{Sampling Site}

The study area is in the Langun-Gobingob cave complex $\left(11^{\circ} 55^{\prime} 56^{\prime \prime} \mathrm{N}\right.$, $124^{\circ} 54^{\prime} 0.5^{\prime \prime} \mathrm{W}$ ) of the Calbiga Karst, in the Municipality of Calbiga, Samar, Philippines. Soil samples from the upper $5 \mathrm{~cm}$ layer of the sediment were taken from ten different areas of the cave complex. The soil samples were collected and placed into sterile plastic bags (Niyomvong et al 2012). The samples were brought to the laboratory and dried in an oven at $65^{\circ} \mathrm{C}$ for $3 \mathrm{~h}$ (Rahman et al 2011).

\section{Isolation of Actinomycetes}

Each soil sample $(1 \mathrm{~g})$ was suspended in $9 \mathrm{~mL}$ sterile distilled water, and the suspension was serially diluted three times by adding $1 \mathrm{~mL}$ of suspension with $9 \mathrm{~mL}$ of sterile distilled water. The soil suspension was heat treated in a water bath at $50^{\circ} \mathrm{C}$ for $6 \mathrm{~min}$. This wet heat treatment is done to target the isolation of Actinomycetes by inhibiting the growth of other bacteria (Jiang et al 2016). The heat treated solution was cooled to room temperature (Duangmal 2005). The resulting soil suspension $(0.1 \mathrm{~mL})$ was plated onto starch-casein $(\mathrm{SC})$ agar plates which were 
supplemented with $10 \mu \mathrm{g} \mathrm{mL}^{-1}$ amphotericin $\mathrm{B}, 75 \mu \mathrm{g} \mathrm{mL}^{-1}$ of fluconazole, and $10 \mu \mathrm{g} \mathrm{mL}^{-1}$ of streptomycin to prevent Gram-negative bacteria, fungi, and other microbes from growing. The plates were incubated at $32^{\circ} \mathrm{C}$ for about 21 days. The actinomycete colonies were identified based on their colony characteristics (Kuster and Williams 1964, Benhadj et al 2018). The suspected actinomycete colonies were isolated using the streak plate method on Glucose-Yeast-Extract (GYE) Agar plates. The plates were incubated at $32^{\circ} \mathrm{C}$ for 7 days (Niyomvong et al 2012).

\section{Characterization}

After the incubation period, the color of the diffused pigment and substrate mycelia were grouped based on the National Bureau of Standards Color Chart (Zhao et al 2006). Other morphological characterization was based on the guidebook Guide to the Classification and Identification of the Actinomycetes and Their Antibiotics (Waksman and Lechevalier 1970).

\section{Molecular Identification}

Subcultures of each isolate were sent to the Philippine Genome Center for $16 \mathrm{~S}$ rRNA extraction and sequencing. The universal forward primer 27f (5'-AGAGTTTG ATCCTGGCTCAG-3') and reverse primer 1492r (5' TACGGYTACCTTGTTACGACTT 3') were used to amplify the $16 \mathrm{~S}$ rRNA gene. The same primers from the reaction were used to sequence the PCR products. The Basic Local Alignment Search Tool (BLAST) program was used to compare the sequences present in the public database (Weisburg et al 1991). The evolutionary history was inferred using the NeighborJoining method (Saitou and Nei 1987). The optimal tree with the sum of branch length $=0.95161525$ is shown. The percentage of replicate trees in which the associated taxa clustered together in the bootstrap test (500 replicates) are shown next to the branches (Felstein 1985). The evolutionary distances were computed using the p-distance method (Nei and Kumar 2000) and are in the units of the number of base differences per site. This analysis involved 11 nucleotide sequences. Codon positions included were $1 s t+2 n d+3 r d+$ Noncoding. All ambiguous positions were removed for each sequence pair (pairwise deletion option). There were a total of 1,722 positions in the final dataset. The MEGA X software was used to construct the phylogenetic tree (Kumar et al 2018).

\section{Test Microorganisms}

Staphylococcus aureus (ATCC 25923), Bacillus cereus (ATCC 10876), Pseudomonas aeruginosa (ATCC 27853), and Escherichia coli (ATCC 25922) were obtained from the Department of Science and Technology (DOST)-Region 8, Palo, Leyte, Philippines. In the laboratory, they were maintained on Nutrient Agar slants and stored at $4^{\circ} \mathrm{C}$.

\section{Screening of the Antimicrobial Potential of the Actinomycetes}

Preliminary screening of the antimicrobial potential was conducted using the methods described previously (Shomura et al 1980). The actinomycete isolates were streaked in a single line across Glucose-Yeast-Extract (GYE) Agar plates. The 
plates were incubated at $32^{\circ} \mathrm{C}$ for 5 days in order to allow the bacteria to secrete antibacterial substances into the medium (Kamat and Velho-Pereira 2012). Two Gram-positive and two Gram-negative bacterial species were used as test organisms. The test organisms were streaked perpendicular to the actinomycete growth line. Subsequently, the plates were incubated at $37^{\circ} \mathrm{C}$ for $12 \mathrm{~h}$. Presence of a zone of inhibition indicates inhibition of bacterial growth.

\section{RESULTS AND DISCUSSION}

Five actinomycete strains Streptomyces sp. strain NMK027, Nocardia caishijiensis, Streptomyces tunisiensis strain CN-207, Streptomyces bryophytorum strain NEAUHZ10, Streptomyces pratensis strain ch24, were successfully isolated from the soil samples collected from the Langun-Gobingob cave complex. Table 1 shows the color grouping of the isolates based on the aerial mycelia.

Table 1. Color of the aerial mycelium and diffused pigments of the isolates.

\begin{tabular}{lccc}
\hline Color series & Isolate Code & Aerial Mycelium & Diffusible Pigment \\
\hline \multirow{2}{*}{ Yellow } & L3A1 & Light Yellow & Yellow \\
\multirow{2}{*}{ Grey } & G2A2 & Strong -Deep Yellow & ND* \\
\multirow{2}{*}{ White } & G3A1 & Light Greenish Grey & Brown \\
& G4A1 & White & Brown \\
& G1A1 & Yellowish White & Brown \\
\hline
\end{tabular}

*ND: No detectable pigment

All isolates were Gram positive. Morphological characterization of the isolates G3A1, G4A1 and G1A1 revealed that they belong to the genus Streptomyces as they excreted brown pigment into the organic medium, and they absorbed moisture from air which condensed on their aerial mycelium (Zhao et al 2006) (Table 1). L3A1 exhibited smooth colonies with greenish yellow surface growth suggesting that this isolate belongs also to the Genus Streptomyces. On the other hand, the colony morphology of G2A2 which showed dry, dark yellow-pale brown, wrinkled colonies is consistent with the characteristics of the Genus Nocardia.

The isolates were further identified by their 16S rRNA using the $27 f / 1492 r$ primers. The resulting nucleotide sequences were matched to the NCBI database by BLAST searching. Table 2 shows the identification of the isolates and their nearest phylogenetic neighbors. Results revealed that four of the five isolates were found to be under the genus Streptomyces while one was found to be under the genus Nocardia. Three of the Streptomyces isolates had matches to the species level. One isolate only had a match at the genus level.

Table 3 shows that isolate G1A1 belonging to the Genus Streptomyces exhibited antagonistic activity against the two gram-positive bacterial species, Staphylococcus aureus and Bacillus cereus. All other isolates did not exhibit antimicrobial activities.

The genus Streptomyces, to which most of the isolates belong, is currently known as the largest among the genera under Actinobacteria. The genus has up to 500 known species (Euzeby 2008). About forty six percent of microbe-derived antibiotics from the 1950s to 1960s were discovered from the genus Streptomyces alone (Tishkov 2001) while only 16 percent was discovered from other genera (Lazzarini et al 2001). Despite the common occurrence of Streptomyces, new 
Isolation, characterization and antibacterial activity of actinomycetes

selective isolation methods have allowed the isolation of actinomycetes from different genera such as Nocardia (Seo et al 2007, Jurado et al 2008). In the current study, a low number of isolates were observed. This could be due to the limited type and number of the media used in the isolation. The use of multiple media and treatments can target the isolation of different groups of actinomycetes (Belyagoubi et al 2018, Jiang et al 2016).

Table 2. Molecular identification of actinomycetes isolated from the soils of the Langun-Gobingob cave complex.

\begin{tabular}{|c|c|c|c|c|c|}
\hline $\begin{array}{l}\text { Isolate } \\
\text { code }\end{array}$ & $\begin{array}{l}\text { Accession number } \\
\text { of nearest neighbor }\end{array}$ & $\begin{array}{l}\text { Percent } \\
\text { Match }^{\dagger}\end{array}$ & E-value ${ }^{H}$ & $\begin{array}{c}\text { Nearest } \\
\text { Phylogenetic } \\
\text { Neighbor }\end{array}$ & Genus \\
\hline G1A1 & MK530210.1 & $100 \%$ & 0 & $\begin{array}{l}\text { Streptomyces sp. } \\
\text { strain NMK027 }\end{array}$ & Streptomyces \\
\hline $\mathrm{G} 2 \mathrm{~A} 2$ & NR_117317.1 & $98.01 \%$ & $2^{-147}$ & $\begin{array}{c}\text { Nocardia } \\
\text { caishijiensis }\end{array}$ & Nocardia \\
\hline G3A1 & NR_133873.1 & $99.12 \%$ & 0 & $\begin{array}{l}\text { Streptomyces } \\
\text { tunisiensis strain } \\
\text { CN-207 }\end{array}$ & Streptomyces \\
\hline G4A1 & NR_146707.1 & $100 \%$ & 0 & $\begin{array}{l}\text { Streptomyces } \\
\text { bryophytorum strain } \\
\text { NEAU -HZ10 }\end{array}$ & Streptomyces \\
\hline L1A1 & NR_125621.1 & $91.58 \%$ & 0 & $\begin{array}{c}\text { Streptomyces } \\
\text { pratensis strain ch24 }\end{array}$ & Streptomyces \\
\hline
\end{tabular}

${ }^{\dagger}$ A higher percent match denotes increased similarity in the sequence.

${ }^{+\dagger}$ Lower E-value, closer to zero or lower, presents a higher threshold of significance of the match.

Table 3. Antimicrobial activity of actinomycetes isolated from the soils of Langun-Gobingob cave complex against bacterial test isolates.

\begin{tabular}{ccccc}
\hline Isolate code & S. aureus & B. cereus & P. aeruginosa & E. coli \\
\hline G1A1 & + & + & - & - \\
G2A2 & - & - & - & - \\
G3A1 & - & - & - & - \\
G4A1 & - & - & - & - \\
L1A1 & - & - & - & -
\end{tabular}

+ Means growth inhibition; - Means no inhibition

The five isolates were qualitatively screened for antibacterial activity against Gram-positive and Gram-negative bacteria. The results show that the isolate G1A1, Streptomyces sp. strain NMK027, exhibited antimicrobial activity against the Grampositive test bacteria. However, it showed no antagonism against the Gramnegative bacteria. This selective activity of actinomycetes against Gram-positive bacteria has also been reported in other Streptomyces species (Thumar et al 2010, Varghese et al 2014). 
The antibiotics produced by actinomycetes in the market encompass many classes including lipophilic antibiotics including ansamycins such as Rifampicin, the broad-spectrum antibiotic Chloramphenicol, and the anti-helminthic Ivermectin (Heidary and Gharebaghi 2020, Holstege 2014, Maddison et al 2008, Raja and Prabakaran 2011). The differential activity of the isolates between Gram-positive and Gram-negative bacteria can be attributed to the morphological differences between these microorganisms in terms of cell wall structure (Singh et al 2014). The cell wall of Gram-negative bacteria is made of structural lipopolysaccharides which constitute an outer polysaccharide membrane layer. This is why lipophilic compounds cannot permeate the cell wall. The Gram-positive bacterial cell wall, however, is only made of a thick peptidoglycan layer which does not have selective permeability against lipophilic compounds (Scherrer and Gerhardt 1971, Moncheva et al 2002). This difference in structure may be causing the selective potency of the isolates against the test bacteria. However, the present study is a preliminary screening and does not isolate the specific bioactive compounds responsible for the activity.

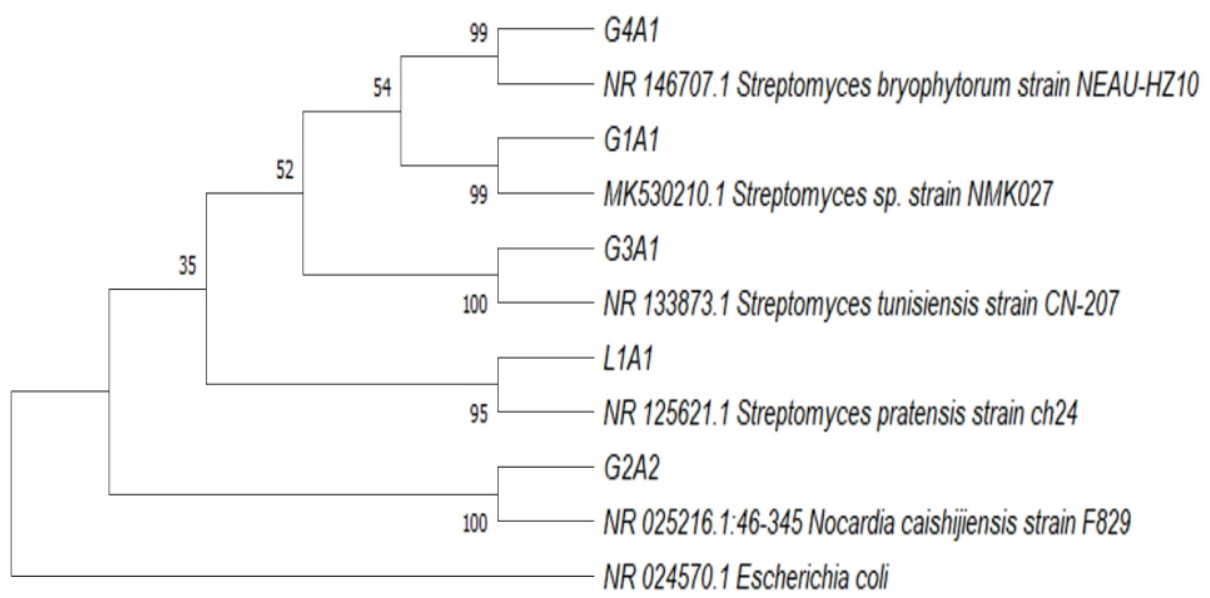

Figure 1. Evolutionary history using the Neighbor-Joining method based on the ITS sequences of the isolated actinobacteria from the soil samples of Langun-Gobingob cave complex and other related bacterial taxa. Phylogenetic tree was rooted with Escherichia coli.

\section{CONCLUSIONS}

Actinomycetes were successfully isolated from the Langun-Gobingob cave complex in Calbiga, Samar. Five actinomycete species were isolated using the starch-case in agar. Analysis of the 16S rRNA showed that 4 of the isolates belong to Genus Streptomyces while one isolate belongs to the Genus Nocardia. However, only one isolate belonging to the Genus Streptomyces showed antagonism against the two Gram-positive test bacteria. This study indicates that the cave complex has the potential to harbor more actinomycete species which can be a source of pharmaceutically significant bioactive compounds. Further study with the use of other isolation methods is recommended. 


\section{ACKNOWLEDGMENTS}

This work was partially supported by the University of the Philippines Visayas Small Budget In-House Research grant through the Office of the Vice-Chancellor for Research and Extension. The authors acknowledge the Department of Environment and Natural Resources Regional Office No. 8 for the permit to collect samples inside the Langun-Gobingob cave complex in Calbiga, Samar.

\section{REFERENCES}

Belyagoubi L, Belyagoubi-Benhammou N, Jurado V, Dupont J, Lacoste S, Djebbah F, Ounadjela FZ, Benaissa S, Habi S, Abdelouahid DE \& Saiz-Jimenez C. 2018. Antimicrobial activities of culturable microorganisms (actinomycetes and fungi) isolated from Chaabe Cave, Algeria. International Journal of Speleology 47(2):189-199

Benhadj M, Gacemi-Kirane D, Menasria T, Guebla K \& Ahmane Z. 2018. Screening of rare actinomycetes isolated from natural wetland ecosystem (Fetzara Lake, northeastern Algeria) for hydrolytic enzymes and antimicrobial activities. Journal of King Saud University-Science 31(4):706-712

Duangmal K, Ward AC \& Goodfellow M. 2005. Selective isolation of members of the Streptomyces violaceoruber clade from soil. FEMS Microbiology Letters 245(2):321327

Euzeby JP. 2008. Genus streptomyces. List of Prokaryotic names with Standing in Nomenclature. http://www.bacterio.cict.fr/s/streptomycesa.html

Felsenstein J. 1985. Confidence limits on phylogenies: an approach using the bootstrap. Evolution 39(4):783-791

Freitas CR. 2010. The role and importance of cave microclimate in the sustainable use and management of show caves. Acta Carsologica 39(3):477-489

Heidary $F$ and Gharebaghi R. 2020. Ivermectin: A systematic review from antiviral effects to COVID-19 complementary regimen. The Journal of Antibiotics 73(9):593602

Holmes AH, Moore LS, Sundsfjord A, Steinbakk M, Regmi S, Karkey A \& Piddock LJ. 2016. Understanding the mechanisms and drivers of antimicrobial resistance. The Lancet 387(10014):176-187

Holstege C. 2014. Rifampin. Encyclopedia of toxicology (3rd edn). Elsevier: Amsterdam, The Netherlands

Jiang Y, Li Q, Chen X \& Jiang C. 2016. Isolation and cultivation methods of actinobacteria. actinobacteria - basics and biotechnological applications. IntechOpen. doi:10.5772/61457

Kamat N and Velho-Pereira S. 2012. Screening of actinobacteria for antimicrobial activities by a modified "cross-streak" method. Nature Precedings 7:1-16

Kumar S, Stecher G, Li M, Knyzac C \& Tamura K. 2018. MEGA X: molecular evolutionary genetics analysis across computing platforms. Molecular Biology and Evolution 35(6):1547-1549

Kuster E and Williams ST. 1964. Selection of media for isolation of streptomycetes. Nature 202:928-929

Lazzarini A, Cavaletti L, Toppo G \& Marinelli F. 2001. Rare genera of actinomycetes as potential producers of new antibiotics. Antoine van Leeuwenhoek 79(34):399-405 
Maddison JE, Watson AD \& Elliott J. 2008. Antibacterial drugs. In Maddison JE, Page SW \& Church DB (eds) Small Animal Clinical Pharmacology (2nd edn) (pp148-185). Saunders/Elsevier

Moncheva P, Tishkov S, Dimitorva N, Chipeva V, Nikolova SA, Nevena K \& Bogatzevska N. 2002. Characteristics of soil actinomycetes from Antartica. Journal of Culture Collection 3:3-14

Nakaew N, Pathom-Aree W \& Lumyong S. 2009. Generic diversity of rare actinomycetes from Thai cave soils and their possible use as new bioactive compounds. Actinomycetologica 23(2):21-26

Nei M and Kumar S. 2000. Molecular Evolution and Phylogenetics. Oxford University Press, New York

Niyomvong N, Pathom-Aree W, Thamchaipenet A \& Duangmal K. 2012. Actinomycetes from tropical limestone caves. Chiang Mai Journal of Science 39(3):373-388

Rahman MA, Islam MZ \& Islam MAU. 2011. Antibacterial activities of actinomycete isolates collected from soils of Rajshahi, Bangladesh. Biotechnology Research International 4:118-123

Raja A and Prabakaran P. 2011. Actinomycetes and drug - An overview. American Journal of Drug Discovery and Development 1(2):75-84

Rangseekaew P and Pathom-Aree W. 2019. Cave actinobacteria as producers of bioactive metabolites. Frontiers in Microbiology 10:387

Restificar SDF, Day MJ \& Urich PB. 2006. Protection of karst in the Philippines. Acta Carsologica 35(1):121-130

Saitou N and Nei M. 1987. The neighbor-joining method: A new method for reconstructing phylogenetic trees. Molecular Biology and Evolution 4(4):406-425

Scherrer R and Gerhardt P. 1971. Molecular sieving by the Bacillus megaterium cell wall and protoplast. Journal of Bacteriology 107(3):718-735

Seo JP, Yun YW \& Lee SD. 2007. Nocardia speluncae sp. nov., isolated from a cave. International Journal of Systematic and Evolutionary Microbiology 57:29322935

Shomura T, Omoto SM, Ohba K \& Ogino H. 1980. SF-1961, a new antibiotic related to bleomycin. Journal of Antibiotics 33(11):1243-1248

Singh LS, Sharma H \& Talukdar NC. 2014. Production of potent antimicrobial agent by actinomycete, Streptomyces sannanensis strain SU118 isolated from Phoomdi in Loktak Lake of Manipur, India. BMC Microbiology 14(1):278

Solanki R, Khanna M \& Lal R. 2008. Bioactive compounds from marine actinomycetes. Indian Journal of Microbiology 48(4):410-431

Thumar JT, Dhulia K \& Singh SP. 2010. Isolation and partial purification of an antimicrobial agent from halotolerant alkaliphilic Streptomyces aburaviensis strain Kut-8. World Journal of Microbiology and Biotechnology 26(11):20812087

Tishkov S. 2001. Bioactive Products from Actinomycetes-antibiotics, Enzyme Inhibitors, Immunomodulators. In Moncheva P, Tishkov S \& Chipeva V (eds) Innovative Aspects in Biotechnology of Prokaryotes (pp111-138). National bank for industrial microorganisms and cell cultures, Sofia

Varghese R, Jyothy S \& Hatha AM. 2014. Diversity and antagonistic activity of actinomycete strains from Myristica swamp soils against human pathogens. Acta Medica Martiniana 14(1):14-19

Ventola CL. 2015. The antibiotic resistance crisis part 1: causes and threats. Pharmacy \& Therapeutics 40(4):277-283 
Isolation, characterization and antibacterial activity of actinomycetes

Waksman SA and Lechevalier HA. 1953. Guide to the classification and identification of the actinomycetes and their antibiotics. University Microfilms, Ann Arbor, Michigan

Weisburg WG, Barns SM, Pelletier DA \& Lane DJ. 1991. 16S ribosomal DNA amplification for phylogenetic study. Journal of Bacteriology 173(2):97-703

Zhao H, Parry RL, Ellis DI, Griffith GW \& Goodacre R. 2006. The rapid differentiation of Streptomyces isolates using fourier transform infrared spectroscopy. Vibrational Spectroscopy 40(2):213-218 